\title{
ARCHEOLOGICKÉ NÁLEZY Z VYHOŘELÉ BAŠTY VNĚJŠÍHO OPEVNĚNÍ KADANĚ. PŘÍSPĚVEK K POZNÁNÍ HMOTNÉ A DUCHOVNÍ KULTURY MĚŠŤANŮ V 17. STOLETÍ
}

\section{KRYŠTOF DERNER}

\begin{abstract}
Abstrakt: Při výzkumu na Studentském náměstí v Kadani byla odkryta bašta vnějši linie městského opevnění pocházejici z přelomu 15. a 16. století. Zanikla požárem kolem poloviny 17. století. Z požárové vrstvy pocházeji sídlištní nálezy, mezi nimiž vyniká erby zdobená kamenina a četné ztrátové mince. Pod podlahu byly zakopány tři hrnce, z nichž dva žrejmě s magickou motivací. Mohlo se jednat o domové obětiny při osvojeni prostoru do té doby neobývané bašty.
\end{abstract}

Klíčová slova: bašta - Kadaň - 17. století-domové obětiny-kamenina.

Archaeological finds from the burnt-down bastion of the external fortification of Kadan̆: contribution to the study of the material and spiritual culture of the bourgeoisie in the 17th century

\begin{abstract}
During excavations in Studentské náměstí square in Kadan̆, a bastion of the external section of the town fortification was unearthed. The bastion comes from the late 15th / early 16th century and was destroyed by fire around the mid-17th century. The fire layer yielded settlement finds including stoneware decorated with coats of arms and numerous coins. Three pots were buried under the floor, two of which were probably associated with magical purposes. They might have been house offerings used to appropriate the space of the previously uninhabited bastion.
\end{abstract}

Key words: bastion - Kadă̌ - 17th century - house offerings - stoneware.

\section{Úvod}

Jádro Kadaně je pro své nesporné urbanistické a architektonické kvality již od roku 1978 městskou památkovou rezervací. Ani přes pozdější námitky archeologů do ní nebyla zahrnuta „,archeologická konzerva“ zaniklé části severozápadního úseku městského opevnění pod někdejším autobusovým nádražím a ve Švermově ulici, tedy severně od dodnes dochované Mikulovické brány. Snad i proto zvítězila v plánu na přestavbu tohoto volného prostranství na náměstí architektonická varianta stavby s rozsáhlým zahloubeným prostranstvím, která je pro zmíněné archeologické situace destruktivní (obr. 1). Při archeologickém výzkumu prováděném Ústavem archeologické památkové péče severozápadních Čech, v. v. i., v letech 2015-2016 zde byly vedle cenných vrcholně středověkých situací pohřbených pod valem opevnění odkryty také oba příkopy, val mezi nimi, složité předbraní Mikulovické brány a bašta vnější linie opevnění (obr. 2). Překvapením bylo zjištění, že tato bašta byla záhy po svém vzniku obydlena a zanikla katastrofickým požárem již v 17. století, čímž došlo k zakonzervování výbavy zdejší domácnosti. Při nedostatku podobných relativně uzavřených nálezových celků nejen v Kadani to lze považovat za velké štěstí (obr. 3). Neobvyklým nálezem volajícím po vysvětlení byly obětiny pod podlahou přízemí bašty. $Z$ těchto důvodů jsme využili př́hodného novověkého tématu konference Archaeologia historica a nálezy z bašty publikovali přednostně.

\section{Historie vnějšího opevnění Kadaně}

Kadaňské městské opevnění před Mikulovickou branou sestávalo v době svého největšího rozvoje ze čtyř linií - hlavní hradby, parkánu zakončeného parkánovou zdí, která tvořila nejspíš i eskarpu vnitřního příkopu, vnější hradby stojící na valu mezi příkopy a hradby předměstí, nejspíš opět s př́íkopem. Vývoj uvedených linií opevnění je dosud velkou neznámou. V. Razím datuje vznik zděného opevnění do širokého rozmezí od 13. století do husitských válek, kdy je Kadaň již dobývána (Razím 1988, 346). Stavba vnější hradby a jejích bašt bývá kladena do doby kolem roku 1458, kdy patrně vznikl barbakán Žatecké brány, jak dokládala nápisová a reliéfní 


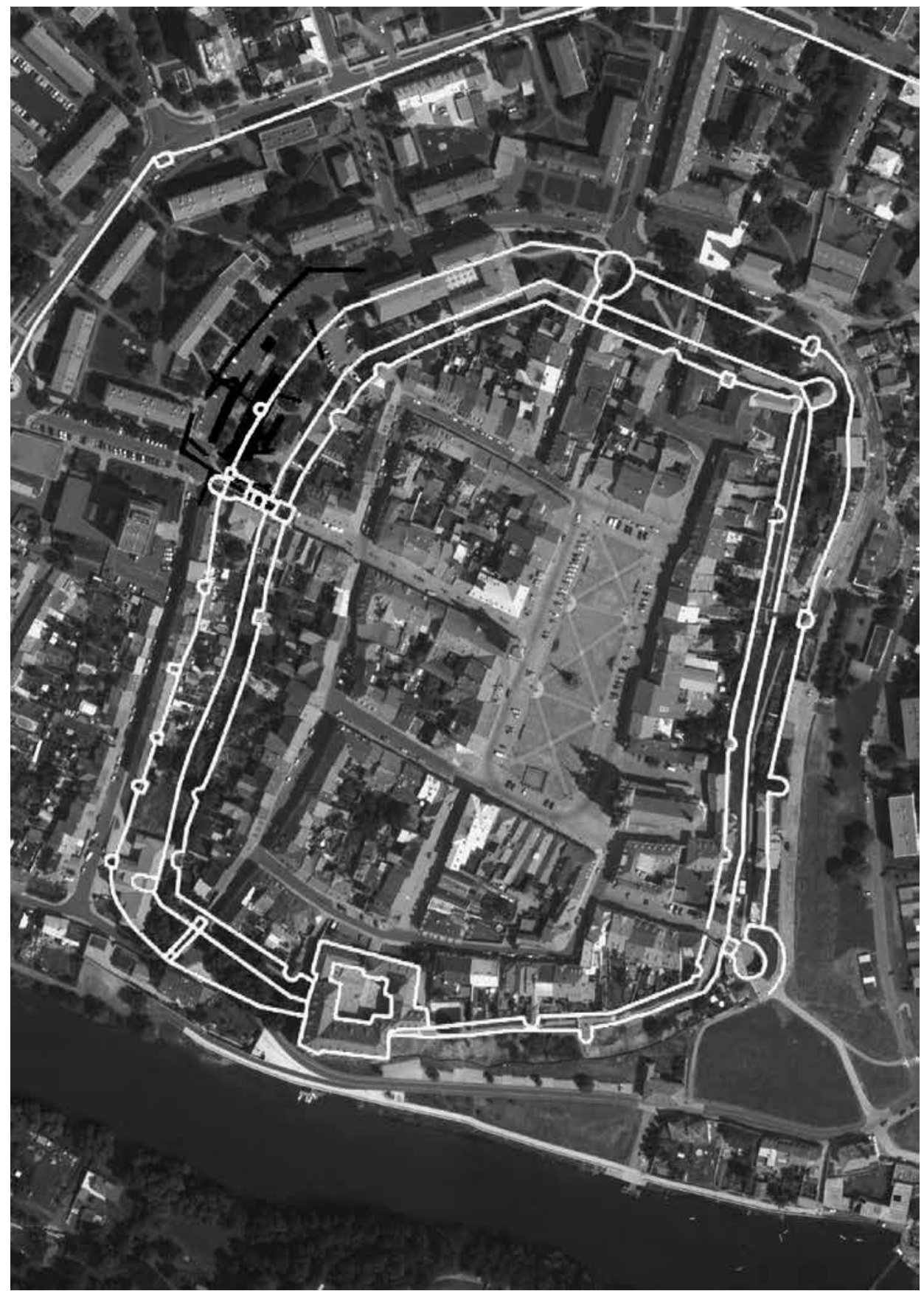

Obr. 1. Poloha výzkumu. Podklad Ortofotomapa ČR, ČÚZK; podle Balášová a kol. 2011, mapový list 29. Bílá - původní rozsah opevnění; černá - plocha výzkumu. Sestavil K. Derner.

Abb. 1. Lage der Grabung. Vorlage Orthofotokarte Tschechiens, Tschechisches Amt für Landesvermessung und Kataster; nach Balášová et al. 2011, Kartenblatt 29. Weiß - ursprünglicher Umfang der Befestigung; schwarz - Grabungsfläche. Erstellt von K. Derner. 


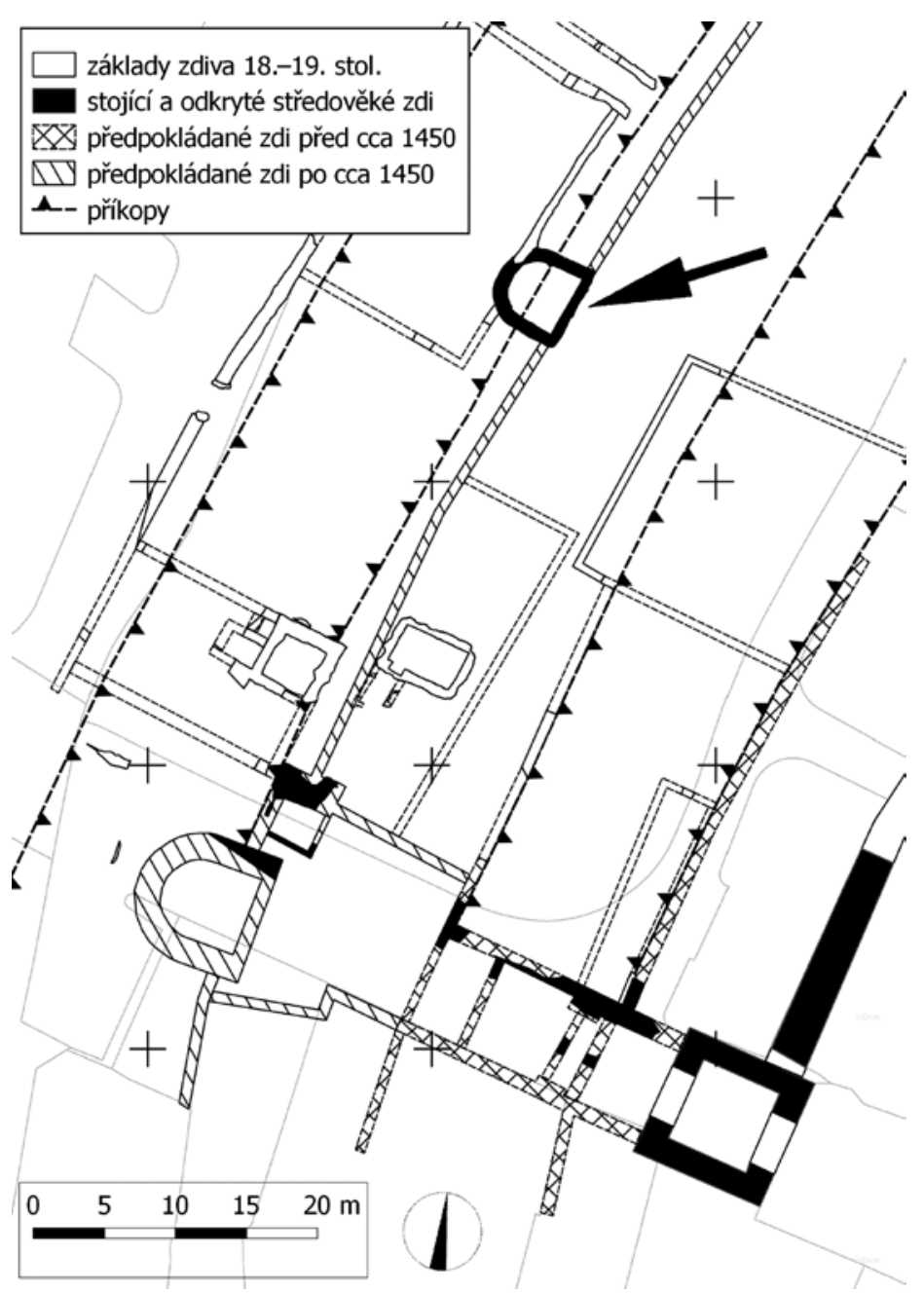

Obr. 2. Plán výzkumu. Zaznamenány jen nalezené zdi. Šipka označuje popisovanou baštu. Vytvořil K. Derner. Abb. 2. Grabungsplanskizze. Eingezeichnet sind nur die entdeckten Mauern. Der Pfeil kennzeichnet die beschriebene Bastei. Erstellt von K. Derner.

deska datovaná k tomuto roku (Hoffmann 1926, 29-30). S barbakánem současný, či starší však musel být jen vnější příkop. Vnější hradba a bašty mohly vzniknout i později. S datací př́liš nepomáhá ani nejstarší dochovaná městská kniha, jejíž zápisy sahají nejhlouběji jen k roku 1465 . Fakt, že u prodeje domů a pozemků se od roku 1475 opakovaně používá obratu „mezi Mikulovickou branou“", bývá zřejmě oprávněně vykládán jako důkaz existence předměstské brány shodného jména (Zahradník 2000,10). Opevnění předměstí však rozhodně netvořilo plnohodnotnou vnější linii obrany, takže obě linie opevnění vnitřního města mohly být posilovány i později. Na stavbu bašt měštany v blízkosti královského hradu si stěžuje jeho zástavní držitel Albrecht Šlik ještě roku 1538, což je ovšem zároveň poslední zmínka o výstavbě nového opevnění v Kadani vůbec (Zahradník 2000, 12, 13). Je otázkou, jak hodnotit sérii prodejů bašt k přestavbě na byty. Mezi Mikulovickou a Vodní branou můžeme roku 1491 zrekonstruovat posloupnost tř́ bašt „na 


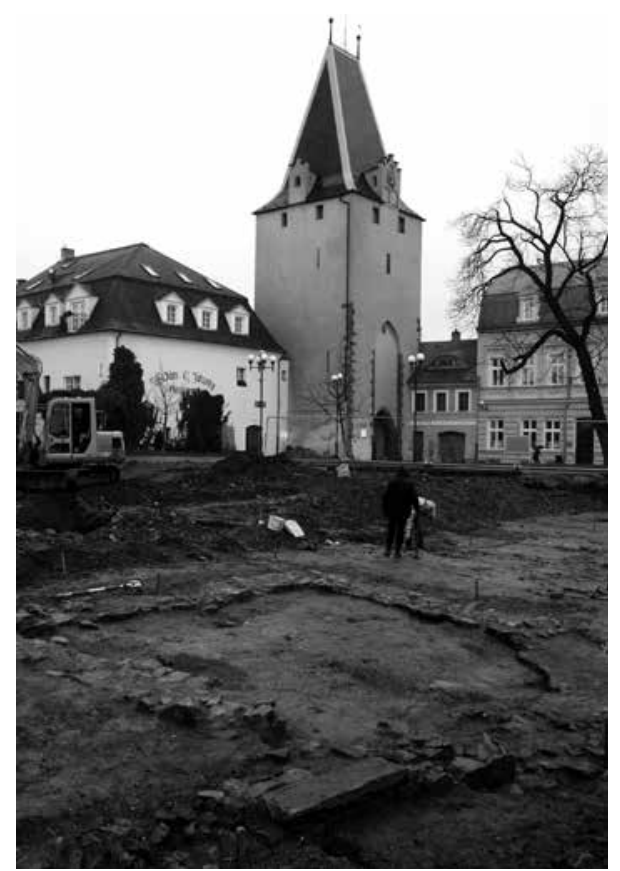

Obr. 3. Pohled od bašty k Mikulovické bráně. Foto K. Derner.

Abb. 3. Blick von der Bastei zum Niklasdorfer Tor. Foto K. Derner.

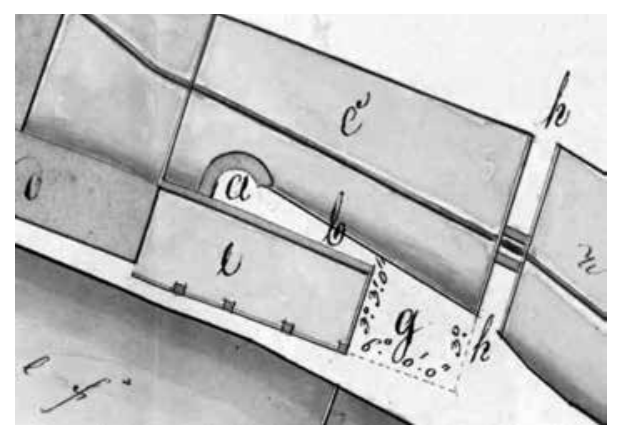

Obr. 4. Plán bašty z roku 1839. a - bašta, b-hradba. Zdroj SOkA Chomutov AMK, kart. 155.

Abb. 4. Planskizze der Bastei aus dem Jahr 1839. a - Bastei, b-Stadtmauer. Quelle Staatl. Bezirksarchiv Chomutov Archiv der Stadt Kadaň, Kart. 155. obecním príkopu“. Roku 1491 prodává Hanns Schmid baštu pod Schapenpogenovou baštou Mathasovi Grapferovi. Téhož roku prodává Linhart Prewer Nickelu Plewerovi baštu pod Grapferem (Stocklöw-Hammer 1890, 366367 , cit. podle Zahradník 2000,11). V tomto úseku stály čtyři bašty $\mathrm{v}$ hlavní hradbě a pět ve vnější hradbě (jedna vybíhala navíc z parkánové zdi). Nelze tedy bohužel rozhodnout, zda k tomuto roku stály již bašty vnější hradby a vojenská situace byla natolik klidná, že již před tímto datem byly $\mathrm{v}$ soukromých rukou, nebo zda se v uvedené zmínce jedná o již nepotřebné bašty vnitřního opevnění, nahrazované teprve v této době opevněním vnějším, př́ípadně, zda nebylo vnější opevnění stavěno až po tomto datu. Jak vidno, písemné prameny neumožňují dataci vnějšího opevnění přesnější než do rozmezí od druhé poloviny 15 . století do první poloviny 16 . století.

O samotné baště ve vnější hradbě severně od Mikulovické brány máme zprávy až v souvislosti s její likvidací. Dne 25. 10. 1839 požádal obchodník Kajetán Egermann o prodej obecního pozemku se starým kusem „(...) kulatého zdiva rondelu, který vrhá do zahrady stín a podstatně brání růstu zahradnich rostlin. Abych odstranil tuto závadu, tak i stálý strach, že budu poraněn padajicim uvolněným kamenim, chci dát toto staré zdivo strhnout a ze ziskaného materiálu zvýšit hluboko ležici cestu pro pěši a zrrídit kanál pro odtok vody, čimž se nejen procházka po př́kopovém valu stane př́jemnější, ale i tamni pusté prostranství se vỉbec stane hezči. " Dne 8. 11. 1839 proběhlo šetření městského hospodářského úřadu, $\mathrm{k}$ jehož dokumentaci byla přiložena i skica dotčených parcel zachycující i baštu a vnější hradbu (obr. 4). Bylo konstatováno, že zdivo rondelu obsahuje již jen jeden a půl sáhu kubického zdiva, takže by materiál nepokryl náklady na demolici. Následujícího roku 1840 proběhl prodej a nejspíš i demolice

(SOkA Chomutov, AMKa). Příkopy byly zasypány a prostor zplanýrován při zřízení tzv. Gymnaziálního náměstí, a dále pak v letech 1881-1882 po jeho rozšíření na Josefské náměstí. V letech 1958-1992 se zde nacházelo autobusové nádraží, vystřídané od roku 1996 tržnicí, přestavovanou v letech 2015-2016 do podoby tzv. Studentského náměstí (Balášová a kol. 2011, 19).

\section{Nálezová situace}

V prostoru Studentského náměstí byla vytvořena snížená plazzeta, v nejhlubším místě zasahující ca $1 \mathrm{~m}$ pod původní povrch. Odtěžovaný materiál tvořil kulturně sterilní zahliněný až 
jílovitý štěrkopísek valu městského opevnění (kontext 1004). Jeho zvrstvení jsme dokumentovali na celkem čtyřech příčných řezech. Pod valem byla $v$ jižní části plochy zjištěna stř̌edověká dřevohlinitá stavba; v severní části plochy byl v nižších partiích valu nalezen základ zděné bašty. Měla podkovovitý tvar, délku i šiř́ku $6 \mathrm{~m}$, vnitřní rozměry $4,4 \times 4,5 \mathrm{~m}$. Zděna byla $\mathrm{v}$ jedné fázi za použití pevné okrové hrubozrnné písčitovápenné malty (obr. 5). Její zaoblené čelo o síle $1 \mathrm{~m}$ bylo založeno do již zčásti zaplněného vnějšího příkopu, zadní část včetně týlní slabší zdi o síle $75 \mathrm{~cm}$ do tělesa valu. K baště byly v novověku přizděny zahradní zdi 1504 a 1509 . Vztah zdiva bašty $\mathrm{k}$ výplni př́ḱkopu byl zkoumán v sondách 15 a 16 . Založení zdiva do již vytvořených uloženin v př́kopu je dokládáno nerovným, „rubovým“ charakterem zdiva a vyhřezávající maltou v celém rozsahu sondy 15 a hlavně pokračováním těchto vrstev i v přední části interiéru bašty. Nejvyšší vrstvy již obsahují hojnou vnitřně glazovanou keramiku, což by svědčilo pro relativně pozdní vznik bašty, nejdříve kolem roku 1500. Interiér byl zkoumán jako sonda 4, nejprve s kř́žzovým kontrolním blokem, později zrušeným. Dochovaná část zásypu interiéru měla velmi jednoduchou stratigrafii: Svrchní šedohnědá písčitojílovitá vrstva 1088 s hojnou cihlovou a maltovou drtí obsahovala velké množství keramického materiálu s četnými prvky charakteristickými pro produkci pozdějšího novověku (18. až první polovina 19. století) a reziduální keramiku 16. či 17. století. Tato vrstva zčásti přecházela i přes ubouranou přední část zdiva bašty, což patrně svědčí pro její vznik již po pokročilé destrukci zdiva, kdy ruina pravděpodobně sloužila jako smetiště (obr. 6). Místy se v téže stratigrafické pozici nacházela obdobně datovaná vrstva 1091. Pod zmíněnými vrstvami ležela šedočerná vrstva 1089, kyprá, hlinitopísčitá s vysokým obsahem uhlíků (do max. $10 \mathrm{~cm}$ ) a uhlíkatého prachu. Obsahovala rovněž zlomky cihel a uvolněné kameny. Jedná se o požárový horizont bašty, jak dokládají i přepálené slepitelné fragmenty nádoby a místy

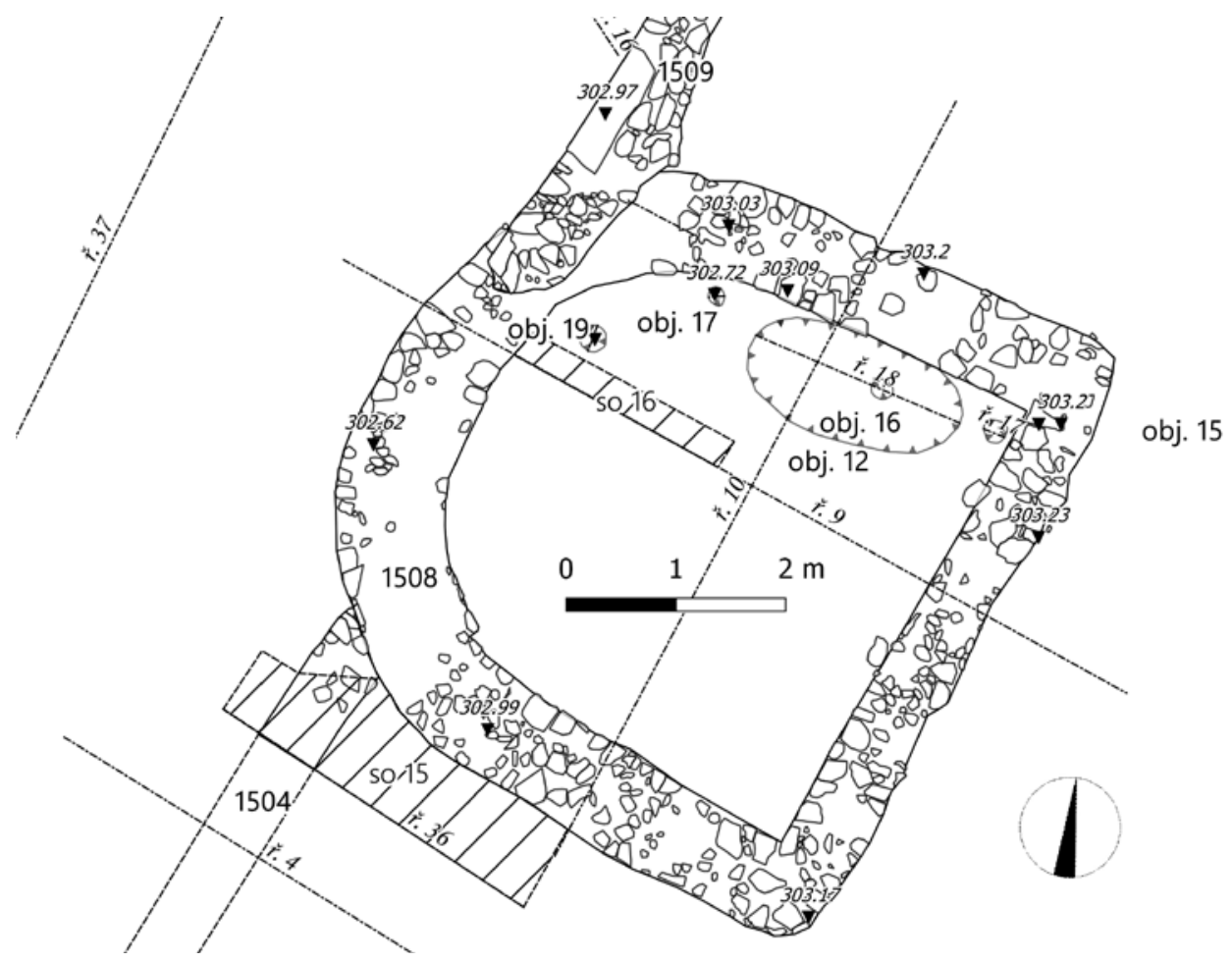

Obr. 5. Půdorys bašty. Vytvořil K. Derner.

Abb. 5. Grundriss der Bastei. Erstellt von K. Derner. 


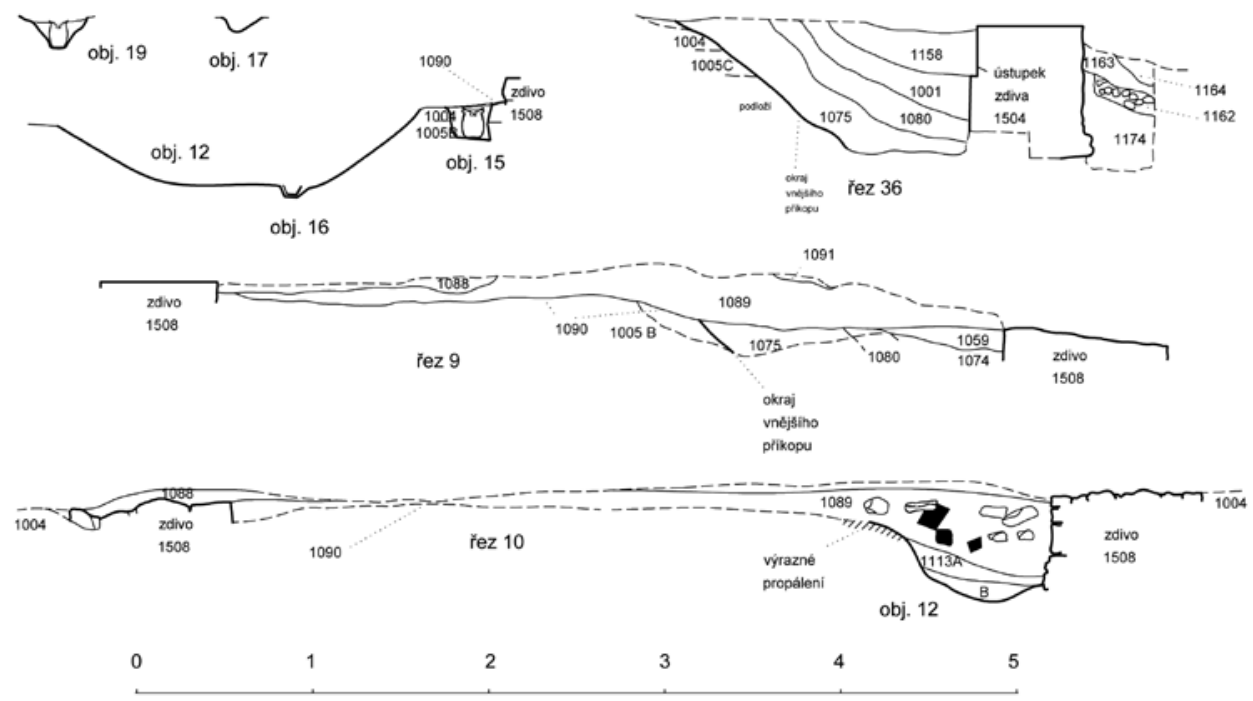

Obr. 6. Řezy. Pozice nádob zaznamenána dodatečně. Vytvořil K. Derner.

Abb. 6. Schnitte. Die Lage der Gefäße wurde nachträglich eingezeichnet. Erstellt von K. Derner.

propálené podloží. Při zpracování nálezového fondu jsme této vrstvě proto věnovali přednostní pozornost. Spíše formálně byla vyčleněna vrstva 1090 - šedožlutě zbarvený povrch písčitojílovitého podloží v zadní části bašty, u nějž ale nebylo jasné, zda se jedná o původní nášlap, nebo o zbarvení ušlapaného podloží nasednutím uhlíkaté vrstvy 1089. Pod vrstvou 1089, resp. 1090 se nacházelo několik jam. Podél severní boční stěny bašty byla až k její základové spáře vykopána oválná jáma - objekt 12/2015 o rozměrech $2,06 \times 1 \times 0,5 \mathrm{~m}$ (obr. 7). Její stěny byly propálené, stejně jako jámou obnažené stěny základu bašty. Vyplňovala ji vrstva 1089, přičemž nejspodnější část výplně byla tvořena prakticky čistou uhlíkatou drtí, označenou 1113. Do dna byl zčásti zapuštěn hrnec, z nějž bylo in situ nalezeno dno a spodek. V severovýchodním rohu byl zakopán hrnec překrytý obrácenou pokličkou (jamka pro něj je označena jako objekt 15/2015). Povrchová vrstvička 1090 byla přetažena přes hrnec, takže byla objevena až po jejím stržení (obr. 8). V čele bašty byl v jamce 19/2015 zapuštěn hrnec opět překrytý obrácenou pokličkou (obr. 9). Uhlíkatá drt' vrstvy 1089 zasahovala do poklesu zásypu nad hrncem. V severozápadní části oblouku čela bašty se v interiéru nacházela ještě mělká jamka 17/2015.

\section{Nálezy hmotné kultury}

Analyzován byl pouze materiál z vrstev 1089, 1090, 1113 a celé nádoby z jamek 15 a 19, tedy nálezy z doby užívání bašty jako obydlí a z jejího dobře datovaného zánikového horizontu (obr. 10). V nálezovém souboru převládá keramika s 1549 fragmenty a dvěma kompletními nádobami. Mezi 17 nálezy z barevných kovů je pro dataci bašty zásadních šest stř́ibrných a bronzových mincí datovaných do období po 1539 až po 1622. Nálezy ze železa jsou zastoupeny 57 kusy především stavebního kování a nožů. Vedle 48 zlomků okenních terčíků byly nalezeny též tři fragmenty skleněných nádob.

\section{Keramika}

Ve vrstvě 1089 bylo nalezeno 1468 keramických zlomků. Z nich bylo 146 zlomků kachlů a 35 zlomků kameniny. Z 1287 zlomků nádob z hrnčiny se podařilo slepit šest velkých 


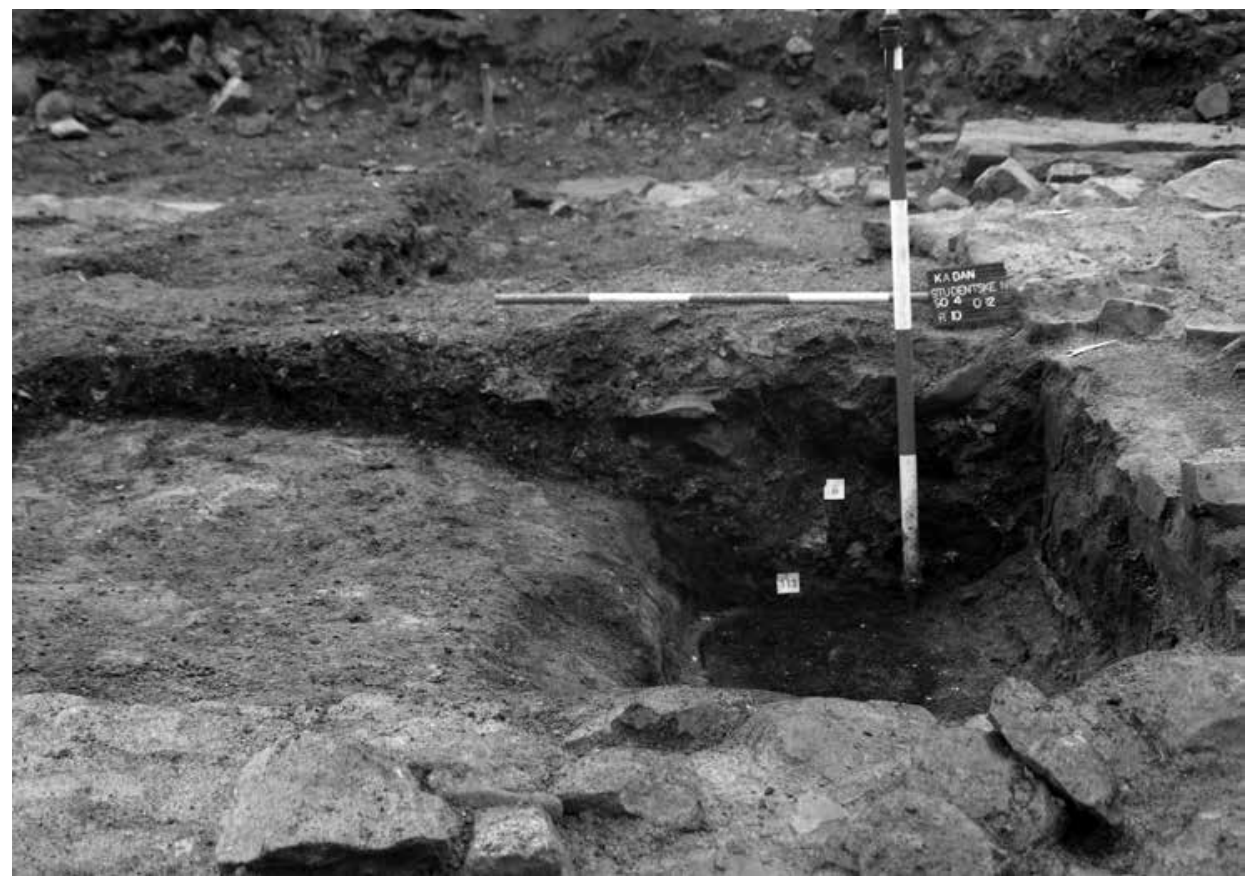

Obr. 7. Jáma 12/2015 vyplněná požárovými vrstvami. Foto K. Derner.

Abb. 7. Mit Brandschichten verfüllte Grube 12/2015. Foto K. Derner.

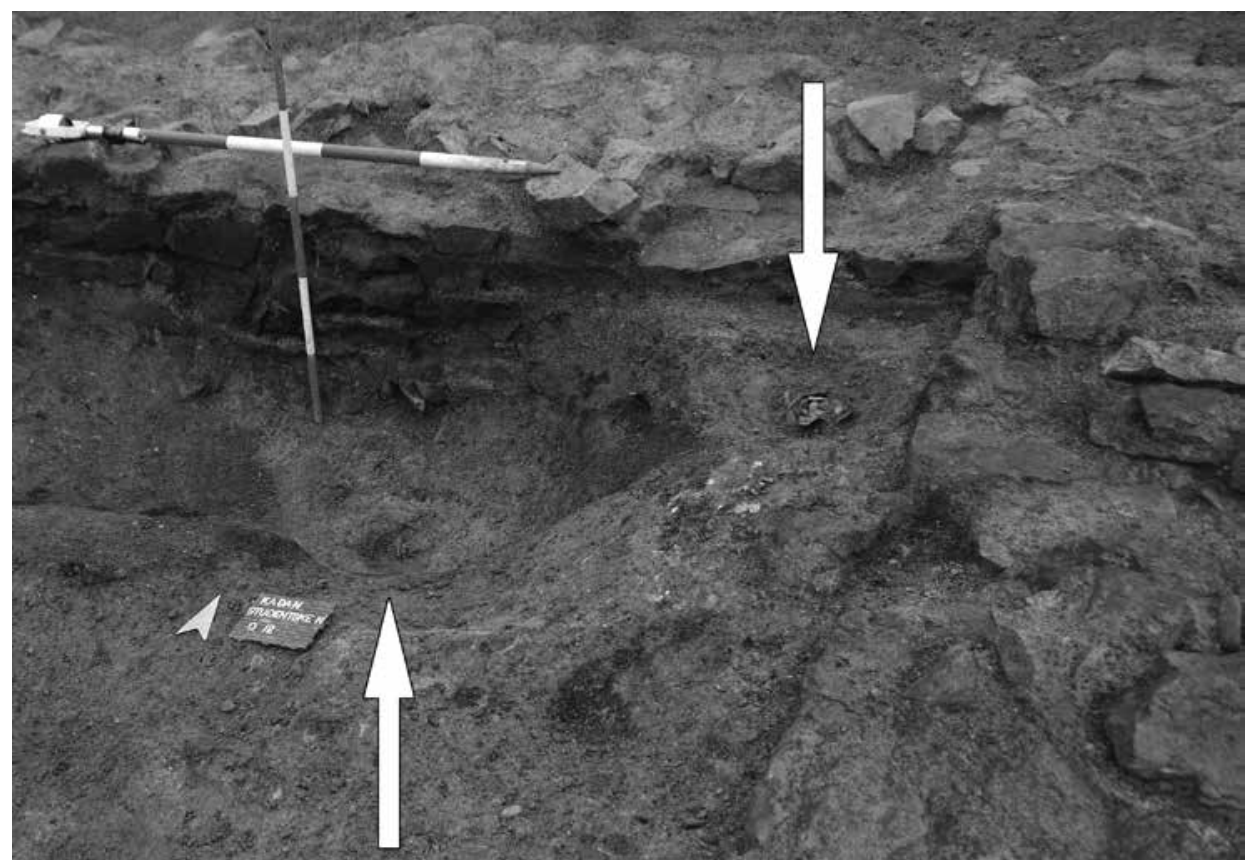

Obr. 8. Zakopané hrnce v jamkách 15/2015 (v rohu bašty) a 16/2015 na dně větší jámy 12/2015. Foto K. Derner.

Abb. 8. In den Gruben 15/2015 (in einer Ecke der Bastei) und 16/2015 auf dem Boden der größeren Grube 12/2015 vergrabene Töpfe. Foto K. Derner. 


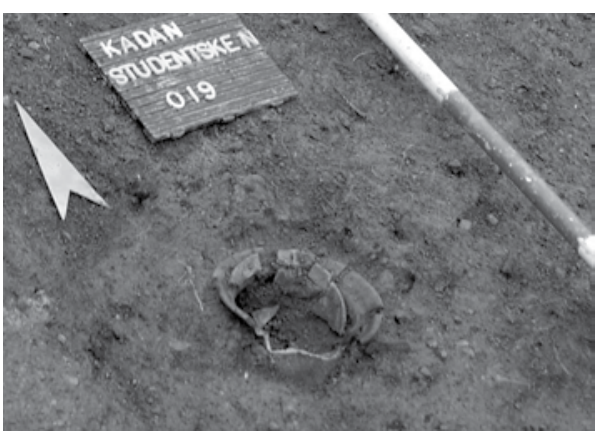

Obr. 9. Hrnec překrytý obrácenou pokličkou - objekt 19/2015. Foto K. Derner.

Abb. 9. Mit umgekehrt aufliegendem Deckel abgedeckter Topf - Objekt 19/2015. Foto K. Derner.

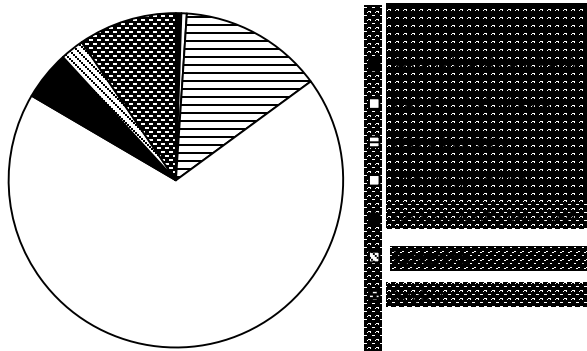

Graf 1. Zastoupení jednotlivých keramických tř́íd v nálezovém souboru.

Diagramm 1. Die im Fundkomplex vertretenen Keramikklassen und -arten. fragmentů požárem přepálených nádob. Mezi keramickými tř́́dami převažuje vnitřně glazovaná hrnčina (graf 1). Barvy glazury zahrnují širokou škálu od žluté přes oranžovou a hnědou $\mathrm{k}$ zelené. Jedno režné přepálené ucho je potékané (žrejmě neúmyslně) glazurou kobaltově modré barvy. Dva zlomky pánví vykazují pokrytí žlutou a zelenou glazurou, jejichž hranice je rozpitá.

Z kuchyňských nádob jsou zastoupeny hrnce, hrnky a hrncovité zásobnie, dále zlomky pánví (5 zlomků den) s nožkami na konci ohnutými a s výrazným otiskem prstu v místě spojení se stěnou nádoby a kónické pokličky včetně uvnitř glazovaných (7 zlomků). Ze stolních nádob oboustranně glazované džbány (viz níže) a ojediněle okraje talířovitých mis (5 zlomků) a jeden zlomek hluboké kónické mísy s výraznými vývalky.

Celkem bylo ve vrstvě 1089 nalezeno 35 zlomků kameniny. ${ }^{1}$ Jedná se o zlomky žlutého lesklého povrchu s vystupující jemnou „krupičkou“, keramická hmota světle žlutošedá až světle šedá na lomu je velmi slabě ostřená. Slepit se podařilo spodek nádoby s podstavou odřezávanou nožem a $\mathrm{s}$ mírně zploštělými stěnami (obr. 10:5). Ze stejné keramické hmoty je i drobné vodorovné páskové ucho (obr. 15:3), jakož i fragmenty s plasticky vyvedenými erby a rozetami (obr. 14). Mezi erby lze s jistotou určit jen saský routový znak, s menší jistotou pak lobkovický znak s orlicí v jednom z polí čtvrceného štítu a břevnem ve druhém. Nedořešený zůstává původ erbu se zkřriženými mečem a klíčem, směřujícími vzhůru, což by odpovídalo znaku biskupského knížectví Naumburg-Zeitz, ovšem v našem př́ípadě s pelikánem v klenotu kolčí přilby, pro nějž neznáme odpovídající vzor. $Z$ dalšího znaku byl nalezen zlomek s přilbou s klenotem ve tvaru toulců se svazky prímých nepřehnutých per (kohoutích?). K nádobě (nádobám) s nálepy asi nepatř́i hrdlo džbánku z podobné hmoty, ale s oříškově hnědým, lesklejším povrchem (obr. 15:1). Výzdoba dalšího džbánu vrubořezem a malinovými nálepy je charakteristická i pro zánikové městské vrstvy z třicetileté války v německých zemích (Scheidemantel-Schiffer 2005, 84-85; obr. 15:2). Miniaturní lahvička na nožce byla vyrobena ze světlešedé, na povrchu černošedé jemně ostřené kameniny (obr. 15:5).

Z 84 kachlů vrstvy 1089 byl jeden římsový (půloblouk, režný), ostatní byly řadové komorové obdélného formátu s komorou tvořenou obvodovou lištou. Až na dva zlomky s dochovanou zelenou glazurou, které mohou být intruzí, byly ostatní režné, prrípadně na čelních vyhřívacích stěnách potažené bílou engobou. Nalezeno bylo 146 zlomků. Deset zlomků čelních vyhřívacích stěn mělo stopy reliéfu. Identifikovány byly dva motivy, první z nich je hlava anděla za štítem - identický motiv byl popsán v souboru kachlů nalezených při výzkumech v kadaňském františkánském klášteře (Smržová 2007, 38-40; obr. 11). Druhým motivem je cyklus křest’anských ctností, jemuž náleží podle shodných detailů architektonického orámování všechny ostatní zlomky. Dobře dochované jsou pouze dvě čelní vyhřívací stěny s rozpoznatelnými postavami. Figura ženy s pohárem symbolizuje patrně víru (Fides; obr. 12). Druhá, odlišná postava má

1 Za určení její provenience jako pravděpodobně waldenburské děkujeme Anně Beerové a Yvesu Hoffmannovi ze Saského úřadu pro archeologii v Drážd’anech. 

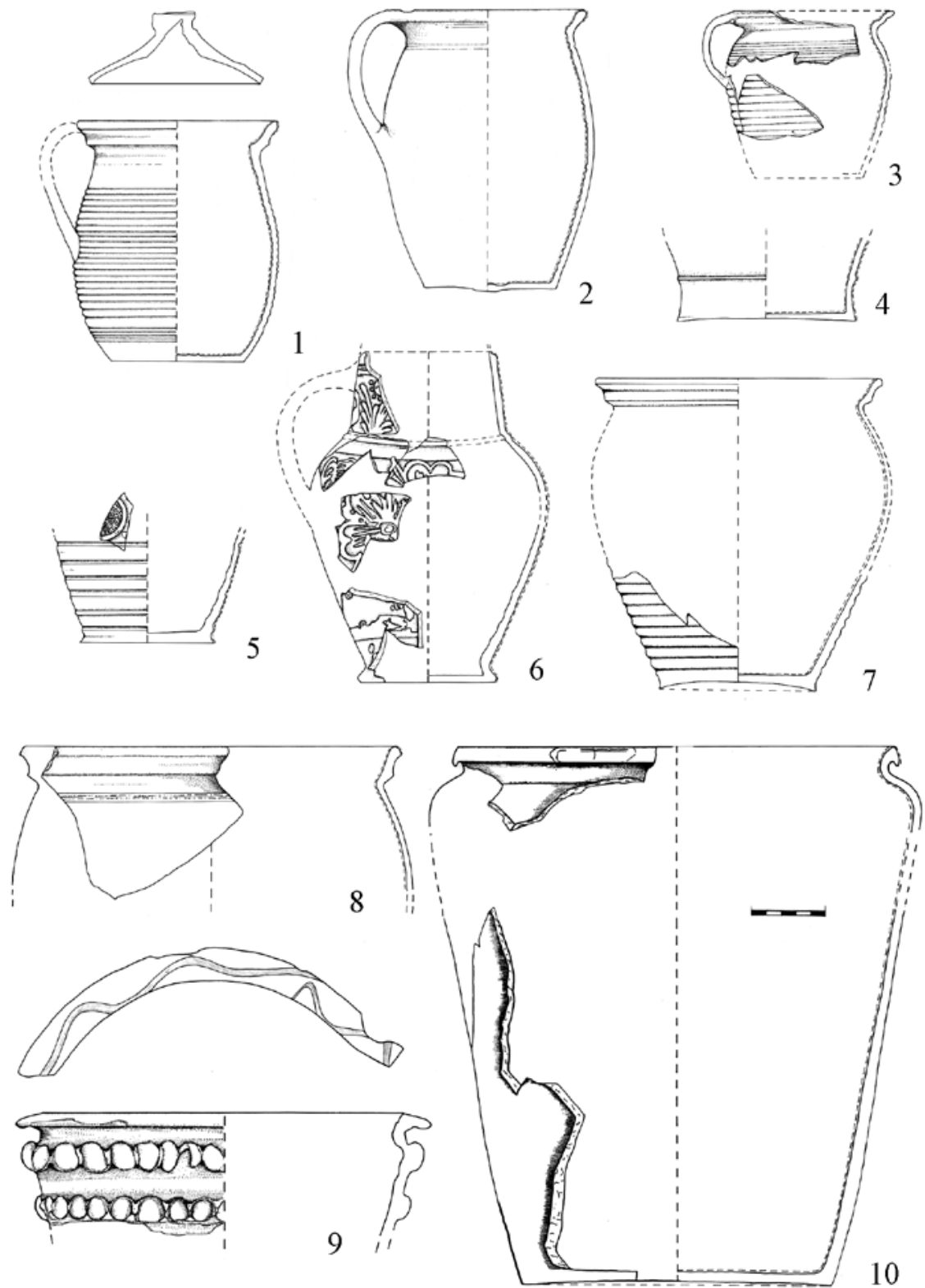

Obr. 10. Nálezy. 1 - uvnitř hnědě glazovaný hrnec z objektu 19/2015; 2 - uvnitř žlutě glazovaný hrnec z objektu 15/2015; $3,4,6,7,10$ - přepálené nádoby z vrstvy 1089. Barva glazury po přepálení: 3 - hnědá, 4 -zelenohnědá, 6 - zelená s hnědým pruhem, 7 - žlutá, 8 - zelenohnědá, červeně malovaná linka, 10 - zelenohnědá, tmavě šedá malovaná linka. 1-4, 6, 7-jemně ostř̌ená hmota, povrch jemně písčitý, barva béžová až světle šedá (u přepálených), 10 - hrubě ostřená, povrch s vystupujícím ostřivem, středně šedý; 5 - spodek kameninové nádoby s plastickou aplikací; 8 - mísa z vrstvy 1113, režná, stř̌edně hrubě ostřená, povrch režný, okrový. Kresba M. Skopařová.

Abb. 10. Funde. 1 - innen braunglasierter Topf aus Objekt 19/2015; 2 - innen gelbglasierter Topf aus Objekt 15/2015; 3, 4, 6, 7, 10 - überbrannte Gefäße aus Schicht 1089. Farbe der Glasur nach dem Überbrennen: 3 - braun, 4 - grün-braun, 6 - grün mit braunem Streifen, 7 - gelb, 8 - grün-braun, rot bemalte Linie, 10 - grün-braun, dunkelgrau bemalte Linie. 1-4, 6, 7 - feingemagerte Masse, Oberfläche leicht sandig, Farbe beige bis hellgrau (bei den überbrannten), 10 - grobgemagerte Masse, Oberfläche mit heraustretendem Magerungsmittel, mittelgrau; 5 - untere Partie des Steinzeuggefäßes mit plastischer Applikation; 8 - Schüssel aus Schicht 1113, unglasiert, mittelgrobgemagert, Oberfläche unglasiert, ockerfarben. Zeichnungen M. Skopařová. 

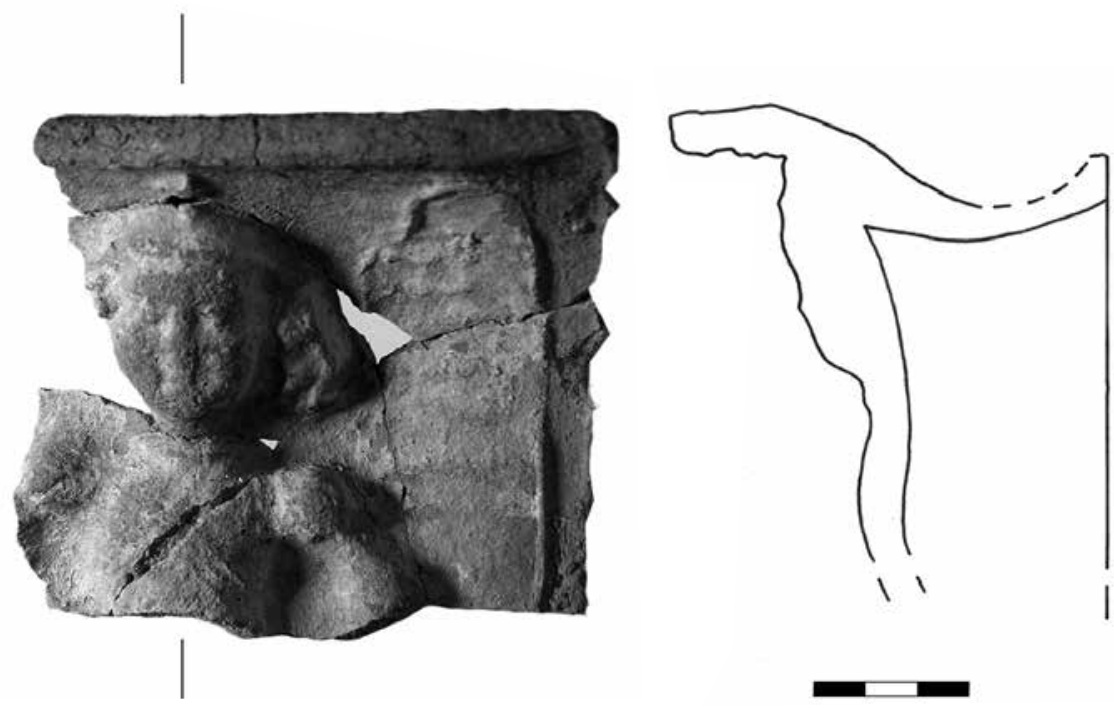

Obr. 11. Zlomek kachle s andělem štítonošem. Foto K. Derner. Abb. 11. Kachelfragment mit Schildhalterengel. Foto K. Derner.

reliéf značně setřelý, rukou směřuje k místu srdce, mohlo by se jednat o lásku (Caritas), zejména pokud by součástí výjevu bylo hořící srdce $\mathrm{v}$ její ruce, což nelze na nepř́liš zřetelném výjevu zcela vyloučit (obr. 13).

Zlomek troubele dýmky z plavené světlešedé hmoty o vnějším průměru $6,8-7,8 \mathrm{~mm}$ nenese žádné chronologicky citlivé znaky. Může se jednat i o intruzi z vrstvy 1088.

Nálezy z vrstvy 1090 se od nálezů z vrstvy 1089 v zásadě neodlišovaly, a to ani velikostí zlomků. Patrně se jednalo skutečně pouze o nejnižší část vrstvy 1089 v kontaktu s podlahou. Z vrstvy 1113 pocházel velký zlomek mísy (obr. 10:9).

\section{Mince}

Z vrstvy 1089 pochází osm mincí. Lze je považovat za ztrátové, at' již in situ (naplocho uložené na povrchu podloží v podlahové vrstvě 1090), nebo při požáru propadlé stropem z vyšších pater stavby. Jejich datace, tedy po 1539 až po 1622, dobře odpovídá jednak uvažované pozdní dataci založení bašty a na druhé straně datu 1623 zjištěnému pomocí dendrochronologie z ohořelého trámu v požárové vrstvě 1089. Mimo dva nevyobrazené malé peníze Matyáše II. (1617 a neurčené datace) jsou detaily provenience a datace ostatních mincí udány v popisku obrázku 16.

\section{Předměty z kovi̊ a předměty ze skla}

U drobných bronzových výrobků se zčásti jedná o doplňky oděvu - jako v př́ípadě záponky ženského opasku (obr. 16:1), pukličky, špendlíků či háčků (obr. 16:3). Zčásti jde o blíže funkčně neurčené objímky, zlomek trubičky a ozdobná kování - bud’to nábytková, či knižní. Pozoruhodný je masivní úlomek bronzu o maximálních rozměrech $6,1 \times 2 \times 1,6 \mathrm{~cm}$ (obr. 16:2). Dvě strany jsou rovnoběžné, rovné, ostatní jsou tvořeny nepravidelnými lomnými plochami. Mohlo by se jednat o zlomek hlavně děla o síle stěny $2 \mathrm{~cm}$ s polygonálním vnějším pláštěm.

Ze železných předmětů stojí za pozornost masivní pant, patrně dveřní, a perforovaný plech s okrajem zesíleným lištou - část cedníku a dále zlomek z ocílky. 


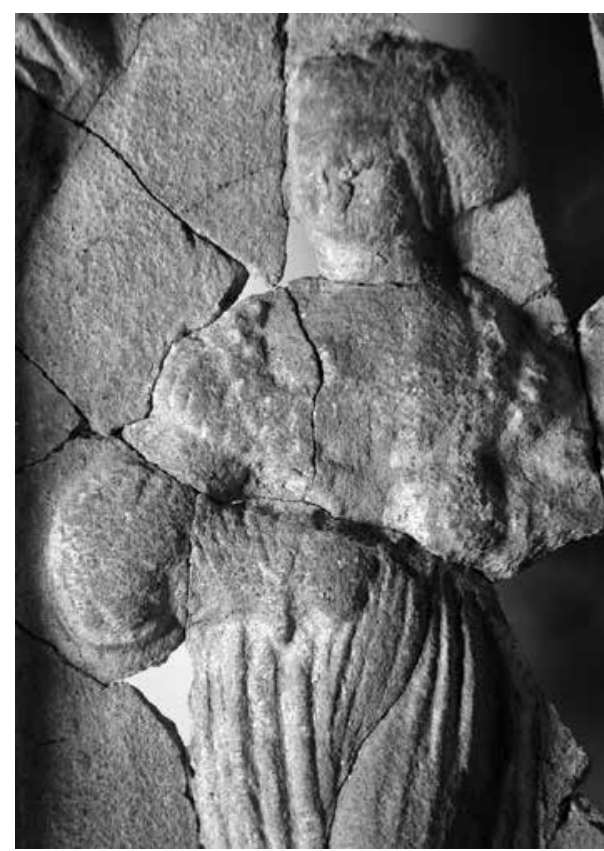

Obr. 12. Zlomek kachle s alegorií lásky (?). Foto K. Derner. Abb. 12. Kachelfragment mit Allegorie der Liebe (?). Foto K. Derner.

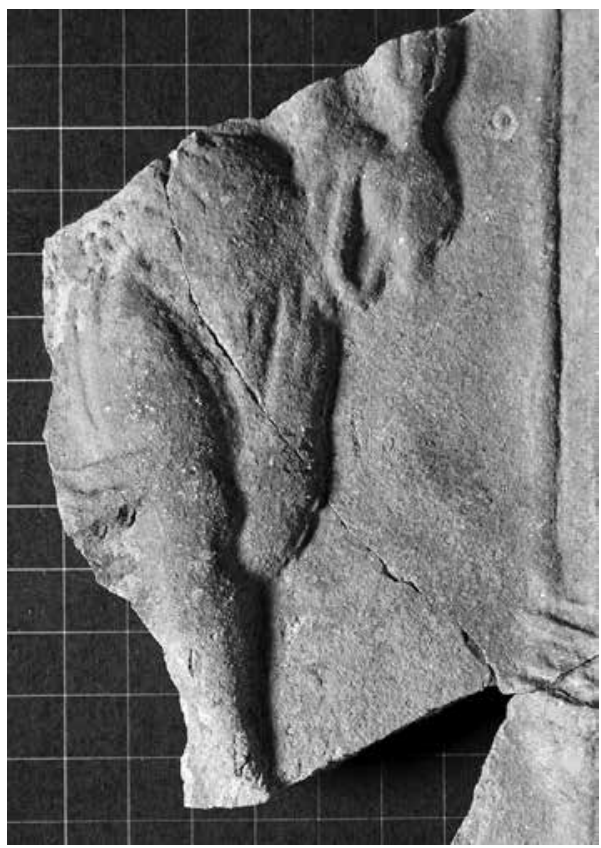

Obr. 13. Zlomek kachle s alegorií víry. Foto K. Derner.

Abb. 13. Kachelfragment mit Allegorie des Glaubens. Foto K. Derner.
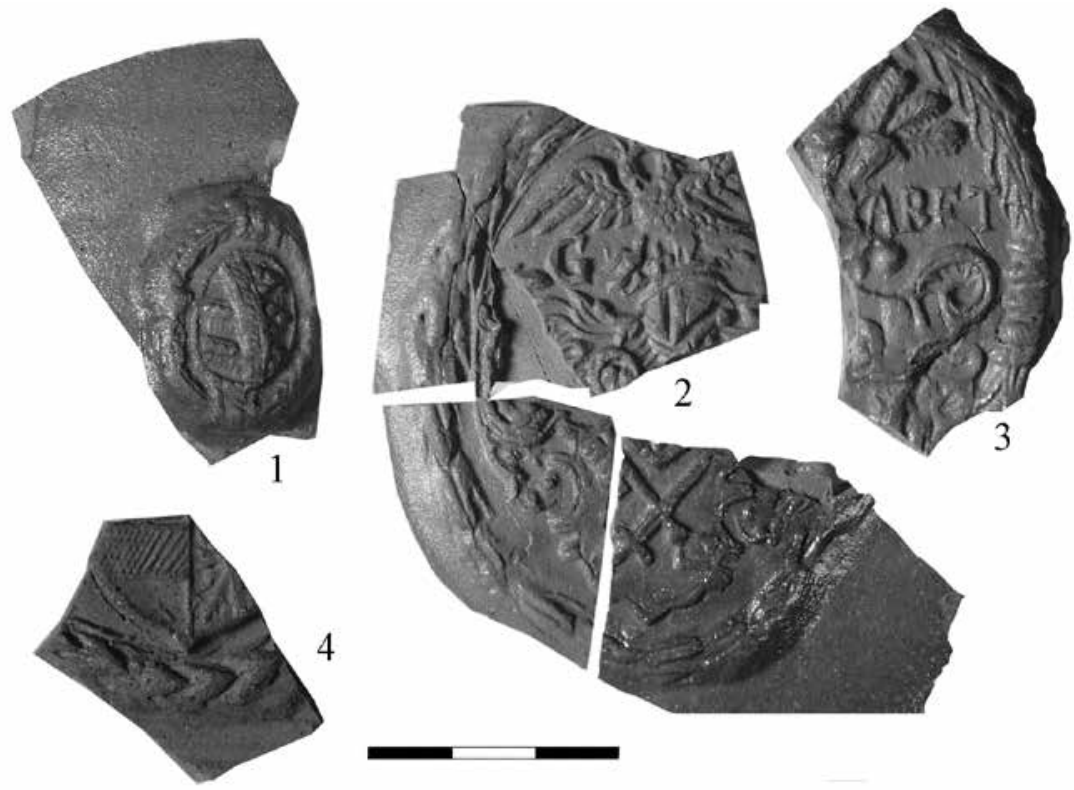

Obr. 14. Plastické aplikace na kamenině. 1 - saský routový znak; 2 - neurčený erb (knížecí biskupství Naumburg-Zeitz?); 3 - neurčený erb; 4 - lobkovický erb. Foto K. Derner.

Abb. 14. Plastische Steinzeugapplikationen. 1 - sächsisches Rautenkranz; 2 - unbestimmtes Wappen (Fürstenbistum Naumburg-Zeitz?); 3 - unbestimmtes Wappen; 4 - Lobkowitzer Wappen. Foto K. Derner. 


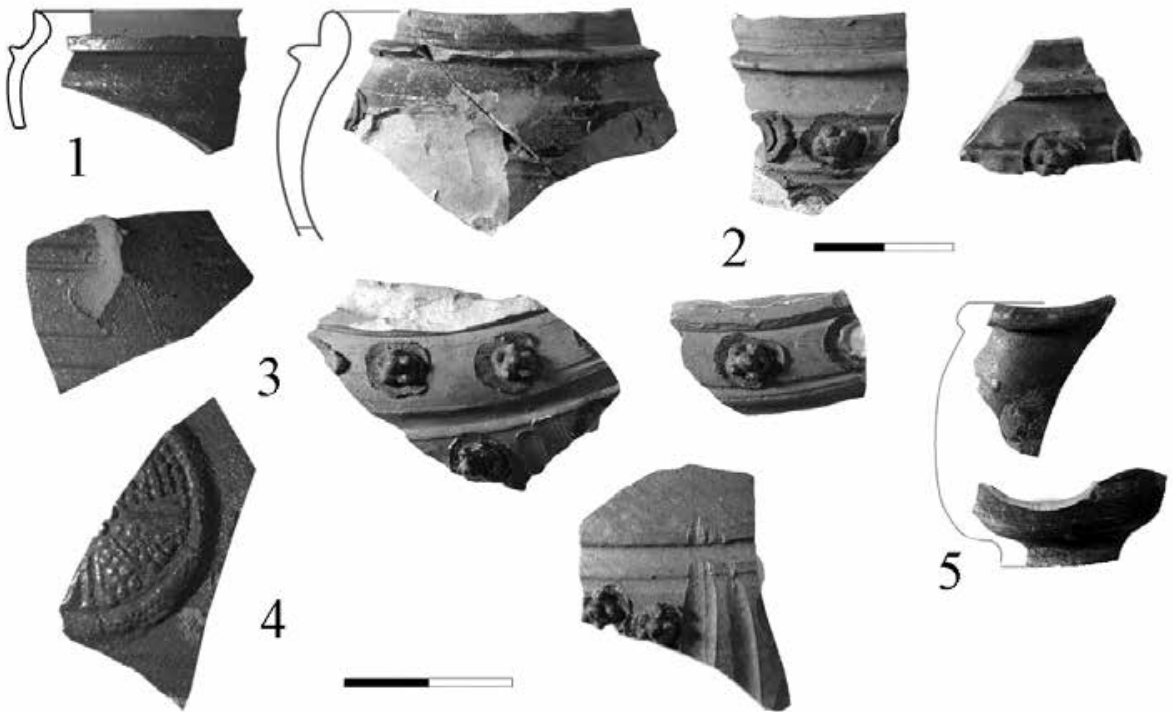

Obr. 15. Kamenina. 1 - pivní džbán; 2 - pivní džbán zdobený malinovými aplikacemi a vrubořezem; 3 - horizontální ouško lahve (?); 4 - rozeta; 5 - lahvička. Bližší popis v textu. Foto K. Derner.

Abb. 15. Steinzeug. 1 - Bierkrug; 2 - Mit Himbeer-Applikationen und Kerbschnitt verzierter Bierkrug; 3 - horizontaler Flaschenhenkel (?); 4 - Rosette; 5 - Miniaturflasche. Nähere Beschreibung siehe Haupttext. Foto K. Derner.
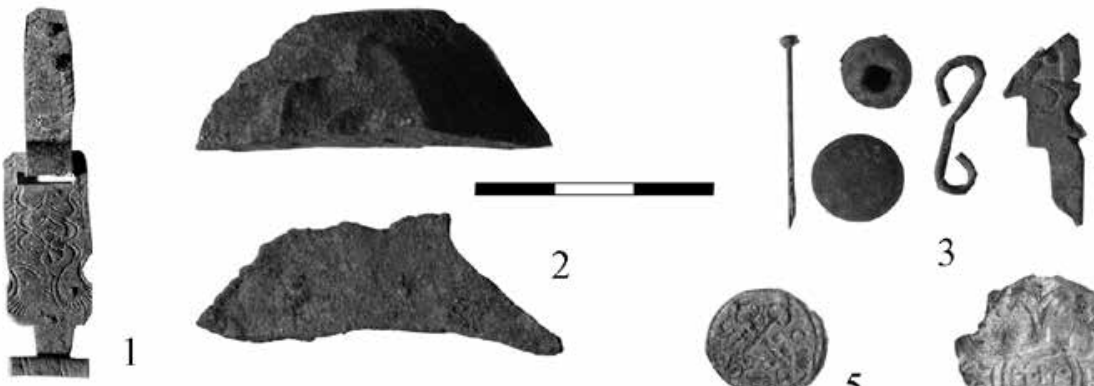

3
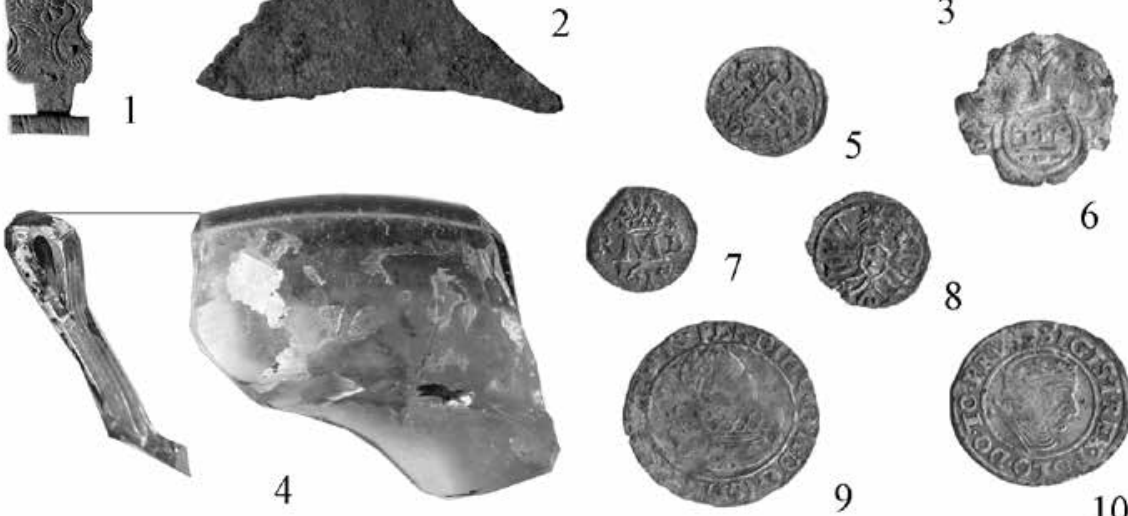

9

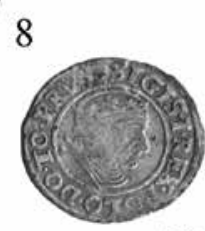

Obr. 16. Nálezy z bronzu, mědi, stř́ibra a ze skla. 1 - záponka opasku; 2 - zlomek bronzoviny z děla (?); 3 - jehlice, puklička objímka, háček, drobné kování; 4 - skleněná miska; 5-10 - mince; 7 a 10 - vrstva 1089, ostatní - vrstva 1090; 5 - stř́íbrný denár Zikmunda III Vasy (Poznaň, 1587-1632); 6 - stříbrný dvojfenik salcburského arcibiskupství za Matyáše Langa z Wellenburgu (po 1519/1540); 7 - měděný malý peníz Matyáše II. (1615); 8 - měděný malý peníz Maxmiliána II. (1562-1576); 9 - stř́ibrný 15krejcar Ferdinanda II. (1622); 10 - stříbrný groš polského krále Zikmunda I. Starého (1539). Foto K. Derner. Abb. 16. Funde aus Bronze, Kupfer, Silber und Glas. 1 - Gürtelschließe; 2 - Fragment einer Bronzelegierung von einer Kanone (?); 3 - Nadel, Knopf Fassung, Haken, Kleinbeschlag; 4 - Glasschüssel; 5-10 - Münzen; 7 und 10 - Schicht 1089, sonstige - Schicht 1090; 5 - Silberdenar von Sigismund III. Wasa (Posen, 1587-1632); 6 - silberner Doppelpfennig des Erzbistums Salzburg unter Matthias Lang von Wellenburg (nach 1519/1540); 7 - Kupferkleingeld von Matthias II. (1615); 8 - Kupferkleingeld von Maximilian II. (1562-1576); 9-15 Kreuzer aus Silber von Ferdinand II. (1622); 10 - Silbergroschen des polnischen Königs Sigismund I. Der Alte (1539). Foto K. Derner. 
Vedle nepočetných zlomků okenních terčíků patří k nálezům ze skla také nízká miska s kónickými stěnami (obr. 16:4) a zlomek stěny skleněné lahve.

\section{Podoba bašty}

Výpověd' movitých a nemovitých nálezů bude pochopitelně vycházet z toho, jakou část bašty jsme zkoumali a jaký byl způsob archeologizace nalezených předmětů.

Domníváme se, že zkoumaný prostor byl přízemím zapuštěným zadní částí do valu. Pravděpodobně se jednalo o chladnou neobytnou prostoru. Značné množství sídlištního materiálu v požárové vrstvě 1089 však podle nás svědčí o existenci obytného vyššího patra. Obdobně je koncipována poslední dochovaná bašta vnějšího opevnění v čp. 187, patrové bašty této linie opevnění ukazuje i Willenbergova veduta. Proti obytnému charakteru př́izemí svědčí malá pozornost věnovaná úpravě podlahy. Sešlapané podloží se sklání k čelu bašty. Dřevěnou podlahu prrízemí patrně nemělo, protože po jejím ukotvení nezbyly ani stopy v nadzemní části zdiva, ani zuhelnatělá konstrukce in situ. Na podlaze též nebyly nalezeny žádné stopy otopného zařízení, což rovněž nasvědčuje spíše provoznímu, neobytnému charakteru místnosti. O osvětlení prostory nemůžeme nic konkrétního říci, lze však vycházet z dochovaných analogií. Až do 19. století se totiž v Kadani dochovalo překvapivé množství bašt s původními stř́lnami, zejména v přizemních prostorech, jako dodnes u čp. 187. Tyto prostory byly také často přestavovány na sklepy na led: „Eiskeller“, jako u čp. 559 (SOkA Chomutov, AMKb), či snad čp. 320 (Hoffmann 1926, 22), v extrémních případech byly v obydlené baště ponechány pouze stř́ilny, jak se situace jeví v baště za čp. 152. O malém množství zasklených oken v baštách svědčí také hospodářské inventáře městské rady, které u obecních bašt evidují jedno až tři okna, ale uvádějí také baštu bez evidovaných oken.

O zabydlení bašty jako celku, patrně ve vyšších patrech, oproti tomu hovoří nálezy z požárové vrstvy 1089. Požár je datován post quem datem smýcení dřeva jednoho z ohořelých trámů z vrstvy 1089: tedy po roce 1623 (smrk bez podkorního letokruhu, analyzoval T. Kyncl jako vzorek X3138). Nelze vyloučit, že zánik bašty souvisí s rozsáhlými požáry Kadaně v letech 1631 či 1635 (Balášová a kol. 2011, 7). Domníváme se, že stavba skutečně zanikla nedlouho po roce 1623 . Po roce 1622 se přestávají hromadit ztrátové mince. Bez významu není asi ani značná sešlost zdiva roku 1839, kdy byl jeho objem již jen ca 2,6 $\mathrm{m}^{3}$ (1,5 kubického sáhu). Původ vrstvy 1089 můžeme hledat jak ve stavebním materiálu z částečné destrukce bašty př́ požáru, tak v předmětech nacházejících se v přízemí, či propadlých shora. O přítomnosti předmětů v baště v době požáru svědčí pět větších přepálených fragmentů nádob a přepáleno bylo i $23 \%$ z glazované keramiky. In situ bylo nalezeno jen jedno dno. Ostatní nádoby byly značně fragmentarizované, a pokud jsme to byli schopni při výzkumu posoudit, tak i značně roztroušené. Lze to přisoudit jejich pádu z vyššího patra. To je pravděpodobné u kachlů, protože žádné stopy po kamnech v přízemí jsme nenalezli. Spektrum a množství nálezů v požárové vrstvě neodpovídá pochopitelně celé výbavě bašty. Nelze vyloučit, že po požáru z ní byly některé využitelné předměty vyjímány, tedy že vrstva byla rozhrabána. Zčásti mohla být odstraňována při postupné destrukci bašty a jejím hroucení se do příkopu, resp. při rozebírání. Nelze ji také považovat za zcela uzavřenou, nebot' se do ní mohly ojediněle dostat intruze z vyšší vrstvy 1088, která se patrně hromadila v ruině bašty sloužící po požáru jako smetiště. ${ }^{2} \mathrm{~S}$ určitou opatrností lze nálezy brát jako svědectví pro obytnou funkci vyšších pater bašty. Zdůrazněme značné množství kuchyňské keramiky, včetně nepočetných, ale přesto př́itomných zlomků pánví, a dále záponky ženského opasku. Obyvatelnost bašty podtrhují také kachle a okenní terčíky. Právě položky na opravy kamen a oken, resp. jejich evidence v hospodářských inventáŕích, se pravidelně objevují v písemnostech městské rady Kadaně v souvislosti s obecními baštami vnější hradební linie mezi Mikulovickou a Vodní branou využívanými v 18. a 19. století jako svého druhu sociální byty, mezi nimiž však již námi zkoumaná bašta chybí (Zahradník 2000, 16, 20, 21).

2 Z nálezů vrstvy 1089 můžeme s požárovou událostí spojit s jistotou přepálené keramické zlomky - pět větších fragmentů a celkem 23 \% glazované keramiky. 


\section{Obyvatelé bašty}

Tím se dostáváme k možnostem sociální interpretace nálezů. Intuitivně bychom do prostor špatně osvětlených, primárně určených k jinému než obytnému účelu umistovali chudinu. Hospodářský inventář z roku 1788 skutečně uvádí jako nájemce baštovních domků kominíka, správce trhu, ženu zvoucí na pohřby, vdovu s pěti dětmi a tři invalidy (SOkA Chomutov, AMKc, cit. podle Zahradník 2000, 20). V tomto případě je ovšem třeba klást důraz na slovo nájemce, jelikož o obyvatelích bašt $\mathrm{v}$ soukromém vlastnictví, kteří mohli být situováni lépe, nemáme zprávy. V první známé vlně prodeje bašt z 90 . let 15 . století jsou skutečně jako majitelé či kupci bašt jmenováni zástupci běžných řemesel jako pivovarník, švec nebo malíř (Stocklöw-Hammer 1890, 366-367, cit. podle Zahradník 2000, 11). Městská rada sama roku 1475 uvádí, že prodej pozemků na městském příkopě je prováděn $\mathrm{k}$ většímu užitku obce a zvětšení počtu obyvatel. Zdá se, že bydlení v baště nebylo vnímáno jako nějak stigmatizující jejich obyvatele, vyplývalo zkrátka z hospodářských zájmů obce. $\mathrm{Z}$ hmotné výbavy domácnosti je ovšem obtížné cokoliv sociálně určujícího vyčíst. Reliéfní kachle ani kamenina (byt' zde se vzácnými erby) nejsou ve vybavení měšt’anských domácností ničím neobvyklým, nehledě na nikoliv nepravděpodobnou možnost, že jejich uživatel na baště nebyl jejich původním objednavatelem. Tím mohli být v případě kameniny s lobkovickým erbem sami Lobkovicové. V 17. století již neměli přímý vztah ke Kadani, ale do roku 1594 byl v jejich držení sousední Chomutov, kde je doložen písemnými prameny dovoz kameniny ze Saska na místní trh (Balášová 2009). V př́ípadě objednávky keramiky zdobené erby se mohlo jednat o propagaci rodu. Na druhé straně je pravda, že u kameniny s erby nelze vyloučit ani obchodní kalkul výrobce kameniny při prodeji do určitého regionu. V písemných pramenech nelze často u kameniny s erby objednávku vysledovat a o vlastní invenci výrobců keramiky svědčí i nepochopené a ledabyle kopírované erby podle všeobecně známých předloh, jako Siebmacherův erbovník apod. (Gaimster-Hildyard 1997, 143, 156, 160).

\section{Domové obětiny}

Konečně je třeba se pokusit interpretovat i nádoby zakopané pod úroveň podlahy. V této situaci překryté obrácenými pokličkami se nacházely hrnec v severovýchodním rohu místnosti (objekt 15/2015) a hrnec zhruba v ose bašty u jejího čela (objekt 19/2015). Případnou skladovací funkci hrnců problematizuje jejich malá velikost. U hrnce v objektu 15/2015 navíc přetažení podlahovou vrstvičkou a konečně i obrácená poloha pokliček ztěžovaly přístupnost obsahu očekávatelnou u skladovacích nádob. Obrácená poloha pokliček mohla naopak usnadňovat jejich překrytí nábytkem, nebo prostě volný pohyb osob v místnosti při dlouhodobé depozici hrnců. Domníváme se, že důvod uložení hrnců byl rituálně magický. Přestože se v hrncích nic nedochovalo, mohly původně obsahovat organickou obětinu, jež podlehla rozkladu, případně symbolizovat „štěstí domu“ samy o sobě, prŕípadně být „pastí na zlé duchy“ (Dančová 2016, 63-64). Náhodná nebude patrně ani lokalizace $\mathrm{v}$ místech, kde mohly být zdi přerušeny otvory: u nároží, kde též mohly do př́zemí sestupovat z týlu bašty schody, a v čele, kde lze předpokládat okenní otvor/střílnu (srov. Vařeka 1994, 131). O stavební obětiny z doby prvotní stavby bašty jako fortifikace se patrně nejedná. Především nebyly stavbou znepřístupněny, což je u stavebních obětin obvyklé, byt' nikoliv nezbytné (srov. definice u Dančová 2016, 9, a Naima-Kräig 2007, 13). Navíc tvar zakopaných hrnců je poměrně pozdní a neodpovídá první polovině 16. století, kdy máme doloženu v písemných pramenech poslední etapu výstavby kadaňského opevnění (Blažková 2013, 191). Mohlo by se tedy jednat o obětinu z doby úpravy bašty na obydlí. Soudě dle plánu demolice bašty z roku 1839 však k výrazným stavebním zásahům do její hmoty nedošlo. Obětina proto nejspíš nesouvisela tolik s adaptací stavby jako takové - v německé terminologii Umbauopfer (Naima-Kräig 2007, 13-14), ale se zabydlením prostoru, dřive k obytným účelům neužívaného, jako tzv. domová obětina (k pojmu Vařeka 1994, 129-132; Dančová 2016, 14-15). Odlišit pak nejsme schopni další možnost, že obětiny byly uloženy ještě později v rámci magického jednání obyvatel domu. Připomeňme nálezy z Bönigsheimu v Bádensku-Württembersku, kde byly 
placenty, o nichž se věřilo, že jsou s novorozencem magicky spojeny i po porodu, ukládány od druhé poloviny 17. století do konce 19. století do hrnců zakopaných pod podlahu sklepů (Kuntner 2004, 284). V Čechách byly nádoby bez makroskopicky patrného dochovaného obsahu nalezeny naprríklad pod podlahou archeologicky zkoumaných domů v Kralovicích (s další literaturou k tématu Čechura 2012, 979-980).

Třetí nádoba - větší vnitřně glazovaný hrnec, z nějž bylo in situ nalezeno jen dno - spočívala na dně větší jámy (obj. 12/2015), do níž bylo z nádoby zapuštěné dno a spodek nádoby (jamka 16/2015). Nádoba nebyla rekonstruována pro značnou fragmentaci. V její výplni bylo nalezeno ptačí vejce. Jáma 12 nebyla v době požáru ještě zasypána, což dokazuje propálení jejích stěn a zasypání požárovými vrstvami 1113 a 1089. V tomto případě uvažujeme spíše o skladovací funkci nádoby umístěné $\mathrm{v}$ jámovitém sklípku, který mohl být překryt prkny, přestože uložení ptačího vejce v nádobě lze rovněž vykládat jako magický úkon, protože skladování vajec vyžaduje sucho, čemuž uložení v nejnižším místě bašty protiřečí.

\section{Závěr}

Ambiciózní otázku po společenské úrovni bydlení na baštách městského opevnění na základě nálezů našeho výzkumu zodpovědět nemůžeme. Jak výměra bytů, tak sociální postavení jejich prvních vlastníků ale napovídá, že se tehdy ještě o „sociální byty“ nejednalo. Zajímavým zjištěním je však již sám fakt, že v Kadani byly tak brzy po dokončení bašty obydleny. Kdybychom se ptali na přesnou dobu, kdy k tomu u naší bašty došlo, obrátíme se asi k výpovědi ztrátových mincí, hromadících se v baště nejspíš od 40. let 16. století, i když jednotlivé mince mohly být tehdy ztraceny i při pohybu zdejší posádky. Otevřenou otázkou rovněž zůstává, zda bašta obydlením ztratila zcela svou vojenskou funkci. Připomeňme řadu obydlených kadaňských bašt s ponechanými stř́lnami. Lze si představit i ponechání jednoho z pater jako obranného, nebo pouze podmíněné obydlení bašty, s tím, že mohly být uvolněny k obraně. Pro první eventualitu známe analogie z bytů branských, ale i obydlení samotných věží opevnění, jak dokládají třeba archeologické nálezy ze sousedního Chomutova, kde byla požárová vrstva spojena s požárem roku 1525 (Nová-Nový-Sýkora 2010, 8). Pregnantním př́íkladem podmíněného obydlení je povolení stavby (sic!) bašty v sousedních Lounech měštanu Špuléřovi k dědičnému užívání, s tím, že k ní v př́ípadě potřeby umožní volný průchod (Razím 2002, 43). V jistém smyslu bylo obydlení baštám prospěšné, nebot' byly udržovány a temperovány. Nález zlomku bronzoviny z děla učiněný při našem výzkumu ale patrně nelze brát za důkaz jeho roztržení přímo v již obydlené baště. Mohlo se jednat i o památeční předmět, surovinu či náhodnou součást zásypu stropů, byly-li použity, apod. Každopádně obydlení bašty znamenalo pro její nové obyvatele vstup do dřive neobydleného prostoru, a proto musely být provedeny rituály jeho osvojení. Tomu podle nás odpovídají domové obětiny nalezené pod podlahou.

Za pomoc při terénní části výzkumu bašty a cenné rady při posouzení kachlů, militarií a erbů děkuji vřele kolegovi M. Sýkorovi. Za určení mincí a pomoc v terénu J. Crkalovi. Za archivní rešerše M. Balášové ze SOkA Chomutov. Zásadní korekce původních interpretací přinesly poznámky v diskusi na vlastní konferenci. Tímto diskutérům za jejich podněty děkuji.

\section{Prameny a literatura}

BALÁŠOVÁ, M., 2009: Nálezy kameniny z hradu v Kadani - Steinzeugfunde von der Burg in Kadaň (Kaaden), AH 34, 85-121.

BALÁŠOVÁ, M. a kol., 2011: Historický atlas měst České republiky. Sv. 23. Kadaň. Praha.

BLAŽKOVÁ, G., 2013: Vývoj raně novověké kuchyňské a stolní keramiky v Čechách na základě souborů z Pražského hradu - The development of Early Modern ceramic kitchenware and tableware in Bohemia based on assemblages from Prague Castle, PA CIV, 183-230. 
ČECHURA, M., 2012: První archeologický výzkum středověkého domu v Kralovicích, okr. Plzeň-sever The first archaeological investigation of a medieval house at Kralovice, Plzeň-north district, ASČ 16, 973-981.

DANČOVÁ, V., 2016: Stavební obětiny ve světle archeologie. Bakalářská závěrečná práce, Filozofická fakulta Univerzity Karlovy. Dostupné z: https:/is.cuni.cz/webapps/zzp/detail/149817/, cit. 16. 4. 2017.

GAIMSTER, D. R. M.-HILDYARD, R. J. C., 1997: German stoneware, 1200-1900: archaeology and cultural history. London.

HOFFMANN, J., 1926: Kaadens mittelalterliche Wehrbauten. Uhl's Heimatbücher des Erzgebirges und Egertales 16. Kaaden.

KUNTNER, L., 2007: Zum Umgang mit Nachgeburt. Plazentabestattung im Kulturvergleich, Curare 27(3), 279-293. Dostupné z: http://www.agem-ethnomedizin.de/download/cu2004-3_Kuntner.pdf, cit. 16. 4. 2017.

NAIMA-KRÖG, M., 2001: Zum Bauopfer in Mittelalter und Neuzeit. Eine archäologisch-historische Annäherung mit Beispielen aus Tirol. Innsbruck. Bakalaureatarbeit. Leopold- Franzens Universität Innsbruck. Philosophisch-Historische Fakultät, der Institut für Archäologien Fachbereich Ur- und Frühgeschichte sowie Mittelalter- und Neuzeitarchäologie. Dostupné z: http://www.academia.edu/21442368/ Zum_Bauopfer_in_Mittelalter_und_Neuzeit._Eine_arch\%C3\%A4ologisch-historische_Ann $\% \mathrm{C} 3 \% \mathrm{~A}$ 4herung_mit_Beispielen_aus_Tirol_, cit. 16.4. 2017.

NOVÁ, E.-NOVÝ, M.-SÝKÖRA, M., 2010: Horní brána v Chomutově, Comotovia 2009, 5-22.

RAZÍM, V., 1988: K počátkům opevnění města Kadaně, Památky a příroda 13, 340-346.

- 2002: K problematice stavební podoby a vývoje středověkého opevnění města Loun, PRP 9, č. 2, 19-50.

SOkA CHOMUTOV, AMKa: Státní okresní archiv Chomutov se sídlem v Kadani, Archiv města Kadaně, karton 155.

SOkA CHOMUTOV, AMKb: Státní okresní archiv Chomutov se sídlem v Kadani, Archiv města Kadaně, karton 362.

SOkA CHOMUTOV, AMKc: Státní okresní archiv Chomutov se sídlem v Kadani, Archiv města Kadaně, kniha 24.

SCHEIDEMANTEL, D.-SCHIFER, T., edd., 2005: Waldenburger Steinzeug - Archäologie und Naturwissenschaften. Veröffentlichungen des Landesamtes für Archäologie mit Landesmuseum für Vorgeschichte 44. Dresden.

SMRŽOVÁ, J., 2007: Kachle z výzkumů františkánského kláštera v Kadani. Bakalářská závěrečná práce, Ústav archeologie a muzeologie FF MU. Dostupné z: https://is.muni.cz/th/64410/ff_b/Kachle_z_Kadane_2007.pdf, cit. 16. 4. 2017.

STOCKLÖW, F. J.-HAMMER, W., 1890: Das Buch der Heimat. Bezirk Kaaden in seiner Gegenwart und Vergangenheit. Kaaden.

VAŘEKA, P., 1994: Význam obřadů a zvyklostí spojených se stavbou vesnického domu pro poznání archaických představ o krajině a prostoru. In: Archeologie a krajinná ekologie (Beneš, J.-Brůna, V., edd.), 126-138. Most.

ZAHRADNÍK, P., 2000: Kadaň. Městské opevnění. Stavebně historický průzkum. Svazek 1. Dějiny objektu. Rkp. ulož. v SOkA Chomutov se sídlem v Kadani, sign. Y-01635/1.

\section{Zusammenfassung}

\section{Archäologische Funde aus der abgebrannten Bastei der Außenbefestigung der Stadt Kadaň (Kaaden). Ein Beitrag zur materiellen und geistigen Kultur der Bürger im 17. Jahrhundert}

Bei der in den Jahren 2015-2016 vom Institut für Denkmalpflege Nordböhmens durchgeführten archäologischen Grabung wurden in Kadaň beim Umbau der ehemaligen Markthallen am Studentenplatz (Studentské náměstí) u. a. beide Stadtgräben, der zwischen ihnen liegende Wall, das komplizierte Vortor des Niklasdorfer Tors (Mikulovská brána) und eine im 17. Jahrhundert abgebrannte Bastei der Außenbefestigungslinie freigelegt.

Ihre Entstehungszeit ist den schriftlichen Quellen nicht zu entnehmen. In Betracht kommt der Zeitraum ab den fünfziger Jahren des 15. Jahrhunderts, als am Schmiedtor (Kovářská brána) eine Inschrifttafel über den Ausbau der Befestigung belegt ist, bis in die dreißiger Jahre des 16. Jahrhunderts, als der Bau der Basteien zum letzten Mal belegt ist. Interessant sind die 
Angaben über den ab den siebziger Jahren des 15. Jahrhunderts erfolgten Verkauf von Basteien und Grundstücken am Stadtgraben unterhalb des Niklasdorfer Tors zu Wohnzwecken. Heute können wir leider nicht mehr feststellen, ob die Basteien der Haupt-Stadtmauer oder bereits die Basteien der Außenbefestigungslinie von dem Verkauf betroffen waren.

Die archäologische Grabung an der Bastei hat ergeben, dass sie in den zwischen den Gräben liegenden Wall eingelassen war und auf der Verfüllung des teilweise schon aufgeschütteten Außengrabens stand. Aus diesen Schichten stammt zahlreiches Keramikmaterial, das ungefähr in das Jahr 1500 oder später datiert werden kann. Die Bastei wurde in einer Bauphase und mit geschlossener Rückwand errichtet.

Auf dem unebenen Fußboden - der dünnen Gehschicht 1090 - lag die Brandschicht 1089. Sie wurde anhand eines abgebrannten Balkens dendrochronologisch in das Jahr 1623 datiert. Eine weitere Quelle für ihre Datierung sind auch Verlustmünzen aus den Jahren 1519/1540 1622. Im Hinblick auf den Charakter der Funde vermuten wir, das die Bastei um Mitte des 17. Jahrhunderts untergegangen ist.

Unter den in der Bastei gemachten Funden ragen mit Wappen versehene Steinzeugfragmente heraus, bei denen es sich wahrscheinlich um Waldenburger Steinzeug handelt. Es gelang uns, den sächsischen Rautenkranz und ein Fragment des Lobkowitzer Wappens zu bestimmen. Die Bestellung dieser Waren, bzw. den Auftrag ihrer Herstellung für den benachbarten Chomutover Markt, bringen wir mit der Famlie Lobkowitz in Verbindung, der Chomutov bis zum Jahre 1590 gehörte.

Unter dem Fußbodenniveau waren drei Töpfe vergraben. Ein - nur teilweise vergrabener Topf befand sich auf dem Boden einer größeren ovalen Grube (Obj. 12/2015), deren Wände durch einen Brand zerstört wurden. Hier ziehen wir in Betracht, dass Grube und Topf eine Lagerungsfunktion hatten. Die anderen beiden Töpfe waren bis zum Hals unter den Fußboden vergraben, und zwar in einer Ecke der Bastei (Obj. 15/2015) und in der Nähe der Basteifront (Obj. 19/2015). Sie waren mit umgekehrt aufliegenden Deckeln abgedeckt. Im Einklang mit der zu diesem Thema veröffentlichten Literatur betrachten wir die Gefäße als sog. „Hausopfer“, die erst nach dem Bau der Bastei deponiert wurden. Wir nehmen an, dass die Aneignung des zuvor unbewohnten Befestigungsbaus durch die erste Familie, die den Bau wahrscheinlich irgendwann in der zweiten Hälfte des 16. Jahrhunderts bezogen hatte, höchstwahrscheinlich der Anlass für das Vergraben der Gefäße gewesen war.

MUDr. Mgr. Kryštof Derner, Ústav archeologické památkové péče severozápadních Čech, v. v.i., J. Žižky 835, 43401 Most, Česká republika, kderner@seznam.cz 
